\section{Parental Choice or School Choice: Who Benefits from the Removal of Zoning?}

\section{CARRIE BEAVEN}

\section{Abstract:}

This article considers the issue of parental choice, a key aspect of the Picot Report and Tomorrow's Schools reforms. It seeks to explore two key research questions pertaining to the secondary school sector. Firstly, does the abolition of school zoning lead to greater parental choice? Secondly, do enrolment schemes create more choice for parents and students? The findings suggest that amendments to the Tomorrow's Schools policy created less choice for some parents, particularly those who were Maori or those of low socio-economic status. It is argued that a level of state intervention is required to ensure fair, transparent selection of students in oversubscribed schools in New Zealand's predominantly state school system.

$\mathrm{P}$ arental choice is a topic of great interest in educational policy. Many groups have an interest in the choice debate - parents, students, educationalists, economists, as well as politicians. In this article I propose to consider two key research questions relating to choice, with a focus on the secondary school sector. Firstly, does the abolition of school zoning lead to greater parental choice? Secondly, do enrolment schemes create more choice for parents and students?

Choice, by definition, implies that there is an opportunity to choose from a range of potential options (Collins, 1993). Thus, choice in an educational context suggests that parents have more than one possible school at which to enrol their children. Zoning, a salient aspect of school enrolment schemes, is closely linked with the choice argument. Prior to the Picot Report (Department of Education, 1988a), school zoning requirements stipulated a public school for children to attend. The designated school was dependent on the age of the student and his or

\section{Carrie Beaven}

her residential location. Out-of-zone entitlements did exist, and some schools did not operate zones, but this was the general pattern. Prior to the removal of zoning, students with more affluent means were able to exercise choice by moving to live in areas linked to more prestigious schools, or through attendance at private institutions. The removal of zoning was to open up the possibility for all parents to exercise the option of choice (Department of Education, 1988a).

The concept of choice comes out of the notion of a free market. Some researchers support the view that the marketisation of education creates a more efficient education system, to the benefit of all students. Market principles are closely linked with economic theses, in particular, that consumers will usually purchase the best product for their money. Therefore, following these principles in the public education system, there is an expectation that parents will enrol their children in the best performing schools (Lauder et al., 1999). This perspective suggests that creating competition between schools, by removing designated zones, creates a system whereby schools that are failing will improve themselves to better compete in the education market. Taking an extreme stance, libertarians argue that choice should be completely unregulated (Peterson, 1998, p. 24).

Conversely, other researchers take the view that competition does not improve educational quality for all students. They argue that a number of students are marginalized by educational markets. In addition, the limitations on resources within the education context, such as teachers and school property, render the place for markets within education as highly problematic (Lauder et al., 1999).

\section{Brief history of zoning policy}

The educational environment in 1988 was very different from that which emerged in the 1990s. In the 1980s only a minority of schools had enrolment schemes. Where zones were in place, a "provider- capture" situation emerged for schools prior to the Picot Report (Waslander \& Thrupp, 1995, p. 22). Overcrowding was not an important issue in the 1980s, due to a decline in the numbers of secondary school-aged students (Prebble \& Halford, 1986, p. 13). However, demographic trends reversed in the 1990s, impacting on the ability of enrolment policies to function effectively in practice. Increased rolls, particularly in Auckland, led to many popular schools being oversubscribed. The enrolment procedures put in place in 1978 to minimise fluctuations in enrolment numbers were clearly becoming outdated by the 1990s (Rae, 2000). The 
Picot taskforce proposed that it was time for a new enrolment system to replace the old one.

Choice was a key value inherent in the Picot Report policies (Codd, 1993), based on the creation of education markets. This policy emphasised self-governing schools, in competition with each other for students (Ainsworth et al., 1993). Students, as consumers, were encouraged to exit poor performing schools to enrol in "better" ones.

However, before the impact that choice policies have on enrolment can be evaluated, it is essential to consider the research outlining how parents make choice decisions. This has a fundamental impact on the implementation of choice policies in New Zealand.

\section{How do parents choose?}

When parents make decisions about schools at which they wish to enrol their children, a number of factors play a role. New Zealand research suggests that the educational value of a school is not the only criterion for selecting a school. Regardless of ethnicity, families that are (or aspire to be) better off, make decisions on the perceived socioeconomic status (SES) of students attending the school, choosing to bypass low decile schools that may be closer (Waslander \& Thrupp, 1995, p. 22). This is an example of parental choice based on a school's perceived social value, and anticipated advantage linked with attendance at a popular school (Ainsworth et al., 1993).

Many studies suggest that marketing is of limited value over and above word of mouth and the reputation of a school (Kemerer, 1999, p. 192). There is evidence that perceptions of particular schools may be reinforced, rather than altered by the use of marketing (Martin, 1998). This suggests that schools experiencing roll decline may be spending valuable resources marketing their school, without directly increasing student enrolments. Such resources could well have been used in providing better educational opportunities for their students. This outcome seems to run counter to the philosophy of Tomorrow's Schools, which emphasises maximum choice for all parents, with the corresponding perceived benefit to all students (Department of Education, 1988b)

After the advent of Kura Kaupapa Maori in 1990, Maori parents now had another option aside from mainstream state education. Students who had attended Kohanga Reo in the 1980s were now entering school age and were looking for ways which would allow them to continue their education through the Maori medium. By July 1996, 11.6 percent of school-aged Maori children were attending Kura Kaupapa (Butterworth \& Butterworth, 1998, p. 250). Alternatively, Maori parents could make choice decision s based on schools that had a Maori bilingual unit, or supported other specialist programmes for Maori. However, it is important to recognise that Kura Kaupapa were born out of increasing initiatives to preserve the Maori language, rather than motivated by choice per se (Thrupp, 1999).

As the above discussion shows, choice decisions do not occur in a vacuum. They are influenced by societal factors as much as by choice issues (Henig, 1994; Schneider et al., 2000). More specifically, the choice of one parent is dependent on the choices of other parents. If more parents choose a school for their children than can be accommodated, there is a discrepancy between supply and demand, which will ultimately mean that some students are successfully enrolled at their school of choice, while others miss out. Zoning, in a sense, established a level of equilibrium between supply and demand. However, the removal of zoning, and consequent provisions for increased choice, led to overcrowding in some popular schools, and raised difficult matters about who decides who will be accepted and who misses out.

\section{How to manage overcrowding}

If free choice is to be mandated, it is essential to have a mechanism to allocate places to students in schools at risk of overcrowding. Fiske and Ladd cite New Zealand data as showing that some schools are indeed perceived as being more popular than others. It follows, therefore, that it will be impossible for all students to attend the school of their choice. Corresponding demographic data from the United States suggest that its population is more diverse than that of New Zealand (Henig, 1999; Statistics New Zealand, 2001). Fiske and Ladd (2000, p. 305) believe that this would create less consensus among United States parents about the best local schools to enrol their children at, therefore creating less overcrowding than in New Zealand, with its more limited number of popular schools.

Economic markets generally balance supply with demand by altering the cost of the item. However, achieving equilibrium between supply and demand in education is more complex. One option to address overcrowding is to allow popular schools to expand to take on all students who wish to study there. However, some schools are unable to increase the number of classrooms on their existing site. There is also understandable resistance by some principals and Boards of Trustees to 
increasing the size of their school. Some argue that larger schools will not provide the most effective learning environment for their students, suggesting an optimum number of students exists for each institution (Evans, 2002). It would appear that, with philosophical objections and current limitations on school property, allowing schools to grow to meet demand is not really a feasible solution to the problem.

Setting up new schools is another option to address excess demand. The Picot Report provides for parents to set up a new school, with government funding. Fiske \& Ladd (2000, p. 283) gave one such example, that of Hutt International Boys School, where parents had the financial means to pay the large operational and other costs. Initially, this puts the financial burden of setting up a school onto parents, placing this option out of reach for many. Also, creating new schools when the existing ones are under-utilised is not an efficient use of a finite pool of resources. Unless more funding can be attracted, setting up new schools is unlikely to resolve the issue of oversubscribed schools.

Enrolment schemes were discussed in Tomorrow's Schools as a means to address overcrowding (Department of Education, 1988b). A school at risk of overcrowding could apply to the Ministry of Education to establish an enrolment scheme. This was arranged between the Secretary of Education and the Board of Trustees (Rae, 2000). Part of this process was a requirement to determine the maximum number of students the school could take. The school would then have to enrol all students that applied, up to this maximum. The enrolment scheme would be required to specify a home zone, guaranteeing right of enrolment to all students residing in this zone. Alternatively, students were able to enrol in the school of their choice (Department of Education, 1988b), but if out-of-zone applications exceeded the number of available places, students would be selected using a random ballot. This was a means to ensure that popular schools did not grow beyond their means, due to increasing demand following the removal of zoning. Policy makers thus did make an attempt to address the issue of overcrowding, but could not foresee the numerous changes to choice policies that were to occur in the 1990s.

The supervised ballot introduced by Tomorrow's Schools was in operation for only one year. There is evidence that random balloting did reduce ethnic and socioeconomic polarisation between schools (Wylie, 1998, p. 80). However, in 1991 significant changes to enrolment policy occurred.
Enrolment schemes following the 1991 amendments

In 1991 the National government eliminated the stipulation of centrally determined zones, making for a more aggressive shift towards a policy of parental choice (Lauder et al., 1999). This reinforced the policy trend of the day, by devolving the responsibility for establishing enrolment scheme criteria to schools (Rae, 2000). Some schools removed the home zone clause from their enrolment schemes completely. Consequently, students who would formerly have enrolled at their local school were now placed in a position of competing for their place at this school. Students were increasingly at the mercy of each school's selection criteria.

Research studies show that low decile schools were the most disadvantaged by the removal of zoning. A number of these schools entered a "spiral of decline". Open enrolment saw the escalation of a "domino" effect, where more advantaged students exited low SES schools to enrol in higher SES schools, and high SES students exited middle decile schools to enrol in high decile schools (Wylie, 1998; Thrupp, 1999). Data from the Smithfield Project show that after the removal of zoning, high SES students were more likely than other students to bypass their local schools in favour of those in higher SES catchments, irrespective of ethnicity (Hughes et al., 1996, p. 28)

There is evidence that in the secondary sector between 1991-98, after the removal of zoning, there was an increase in the median rolls in schools with decile ratings of 6-10 ( $\mathrm{mid} / \mathrm{high})$. At the same time, lower decile schools lost many Pakeha students, leaving predominantly Maori and Pacific Island students in the lower decile schools (especially deciles 1-3) (Harker, 2000, p. 5). Increased stratification of enrolment patterns cannot be explained by shifts in demographic and residential patterns (Fiske \& Ladd, 2000). This suggests that the abolition of zoning did not increase choice for all students, as a considerable number of students were "left behind" in less well-performing schools.

Research shows that enrolment schemes were more likely to be imposed in areas of high roll growth, and especially in higher decile schools. In 1997, approximately 30 percent of decile 8-10 schools had enrolment schemes, compared with 9 percent of decile 1-3 schools (Ministry of Education, 1998). Neither Christchurch nor Wellington had enrolment schemes in existence in decile 1-4 schools (Fiske \& Ladd, 2000 , p. 221). Although these figures include primary schools as well as secondary, a number of New Zealand studies provide evidence that schools with high middle class intakes were those most likely to be 
oversubscribed (Ainsworth et al., 1993; Lauder et al., 1999, p. 110).

Enrolment schemes also became a means for some schools to avoid difficult-to-teach students. In effect, schools that were popular became insulated from the market, as they were no longer competing for students, but were in fact selecting from an oversupply of students wishing to attend (Hughes et al., 1996). Maori students had the lowest chance of entry, even when prior achievement and SES were taken into account (Lauder et al., 1999, p. 62). In 1997, approximately 90 percent of students attending decile 1 schools were of Maori or Pacific Island descent (Fiske \& Ladd, 2000, p. 234).

It is arguable that popular schools did not want to risk losing their image (and subsequent Pakeha enrolments), by accepting too many Maori students. Thus, working class students of Maori and (to a lesser extent) Pacific Island origin were more likely to be disadvantaged by removal of the compulsory ballot, having less chance of acceptance at their school of choice than Pakeha students (Wylie, 1998). Schools applying enrolment schemes without use of a ballot could use them as a means to guard and maintain their established image (Gordon, 1997, p. 73). Thus, some parents were given increased choice to the detriment of others, particularly parents of students with Maori or low-SES backgrounds. Thrupp (1999) suggests that the only way that schools would not lose their competitive edge in the market for students would be if the power of selection were to be removed from schools. This suggested a return to state intervention, for example, through reinstating the compulsory ballot.

Schools with a positive image adjacent to schools with enrolment schemes may benefit from such schemes being in place, as students who are turned away due to over-subscription require a nearby school to attend. The value of this is largely dependent on whether or not the enrolment scheme used by the school utilises a ballot for students competing for a limited number of places. If the school with an enrolment scheme is "hand picking" its students, the surrounding schools may be forced to take students perceived as having less to contribute to the school community.

When the compulsory ballot for out-of-zone students was removed, not all schools chose to eliminate it as their means of selecting students. Although the ballot can be seen as a mechanism for preventing choice, the issue of how to allocate students fairly to overcrowded schools is of primary importance in any choice system. The Smithfield data provide evidence that where oversubscribed schools use a ballot for the remaining places, their rolls are less likely to be biased than are the rolls of schools who pick their students (Lauder et al., 1999). Schools that select their own students are able to choose those they perceive to be the best applicants. If educational attainment is one component of the criteria for accepting or declining an application, this implies an implicit judgement of the type of knowledge that is valued, and conversely that which is not valued. At a secondary school level, selection on the basis of attainment on tests and examinations is much simpler than selection on the basis of less easily available and more intangible measures of practical, cultural or artistic skills. I would argue that entry to a school on equal grounds with other applicants through a random allocation process may be preferable to "hand picking" students, which may put a limitation on a school's contribution to the collective good by introducing undesirable bias.

\section{What about schools at risk of failing in the marketplace?}

To begin with, little support was given to struggling schools (Fiske \& Ladd, 2000, p. 307), largely in keeping with the self-managing concept of Tomorrow's Schools. This provided no safety net for these schools, with the delegation of all responsibility to the school to resolve its own problems at a local level. Subsequently, the Ministry of Education did step in, largely under public pressure, and developed a schools support strategy for those schools perceived to be at risk. However, this was regarded as something in the nature of a "band-aid". On occasions, the Ministry used its right to remove a Board of Trustees, suggesting the issue was one of poor school management. However, studies carried out to determine how parents choose a school suggest that a variety of complex societal factors contribute to their perception of whether a particular school is a good choice or not. It is not a straightforward decision.

School management within the local school community was also adversely affected by the removal of zoning. In the resultant competitive environment, traditional networking between some schools decreased (Wylie, 1994). Distrust of other schools competing for the same limited supply of students could create rifts within professional collegiality, unless they chose to work together, in school cluster relationships, for example (Lauder et al., 1994, p. 63). This is another adverse effect of the marketisation of education, as a lack of sharing of pedagogical and other ideas between local schools can impact on the variety of educational opportunities provided for students. 
Although lower decile schools receive a higher rate of funding per pupil than higher decile schools, the impact of students exiting to enrol at other schools resulted in increased financial hardship for lower decile schools. Ongoing operational costs did not reduce significantly to reflect the drop in student numbers (Gordon, 1997). There is also evidence that low decile schools, and some schools in areas such as South Auckland, became the "dumping ground" for students perceived as "difficult". This had further financial implications for these receiving schools, as these students were often more expensive to teach, requiring more resources and support than more advantaged students, who were often exercising their choice by exiting these schools for greener pastures.

Some choice advocates believe more funding per student should be granted for marginalized students (Chubb \& Moe, 1990). The rationale behind this is the belief that if these students are perceived as being a significant cost to the school over and above their per capita funding, then increasing the funding to cover the cost of educating them will put them on a level playing field with other students. This is contingent on schools being motivated to take on "at risk" students, due to the larger funding linked with each "at risk" enrolment. But it also raises the spectre of inappropriate labelling of students. This must be a potential area for future research in New Zealand.

\section{A return to Tomorrow's Schools?}

The 1997 Education Amendment Bill addressed the issue of enrolment schemes. A new section to the Bill outlined the "Principles governing content and implementation of enrolment schemes." (new section 11B).

(1) When developing, adopting, amending and implementing an enrolment scheme, a Board must, as far as it can, ensure that the enrolment scheme:

(a) Excludes from the school no more prospective students than is necessary to avoid overcrowding at the school

(b) Reflects the desirability of students being able to attend a reasonably convenient school

(c) Enables the Secretary to make reasonable use of the existing network of schools, by taking into account the location and capacity of other schools that are reasonably convenient schools for students in the general area served by the school.

(2) When developing, adopting and implementing an enrolment scheme, a Board must, to the extent that it is reasonable and practicable to do so without derogating from the principles in subsection (1), ensure that students can attend a school of their choice. (cited in Rae, 2000, p. 54)

This legislation recognised the need to balance school choice with school enrolment capacity. However, it did not extend far enough to ensure fairness through designating a transparent home zone for schools with enrolment schemes, nor did it ensure fairness in selection of out-of-zone students. These oversights were addressed in the Education Amendment Act 2000.

In 1999, the Government intervened to require approval by the Secretary of Education for a school to use an enrolment scheme (Fiske $\&$ Ladd, 2000, p. 284). The Ministry was also able to remove a school's right to use an enrolment scheme, in effect sending the school back to competing for enrolments. Students were now guaranteed enrolment in their local school at any time during the academic year. These legislative changes indicate that enrolment schemes after the 1991 changes were not in fact as successful in allowing some parents open choice of secondary school as the original policies had suggested.

The 2000 Education Amendment Act required all schools with an enrolment scheme to specify a home zone (Rae, 2000, p. 49). It also reinstated the ballot to ensure transparency and fairness in the selection of other students. Open enrolment continued for schools without enrolment schemes. Prior to the removal of zoning, families had a "positional advantage" in the education market if they could afford to buy a home within the home zone of a popular school. The actions of secondary schools which select students based on their SES further reinforce the perception of power that already exists for more affluent families, bringing about a sense of educational elitism in New Zealand. Some believe that reinstating a home zone is a paradox and of detriment to lower SES families, as selection by mortgage or residential area has been reinstated. If student applicants have an equal chance of selection by out-of-zone ballot, then means do exist for low-SES students to be accepted into an oversubscribed school, something which was an unaffordable option under zoning. But this is still dependent on the school zone and capacity to allow for this out-of-zone "top-up".

Reinstating a home zone for all schools with enrolment schemes in the 2000 Education Amendment Act led to incidents of fraudulent enrolments. Cases became known of students being accepted into a popular school through use of a temporary address, the address of a relative, or a false address, within the home zone of a school with an enrolment scheme (Real Estate Institute of New Zealand, 2001). 
Consequently, legislation was passed taking a harder line on parents who enrol their children dishonestly. Under this legislation, if an enrolment has been falsified the student may be removed from the school (Evans, 2002, p. 4).

Removal of zoning also made it difficult for some schools to plan effectively for the academic year. It adversely affected two specific groups - schools in the lowest deciles which were experiencing declining rolls, and schools in areas where rapid population increases were occurring - parts of the Auckland region, for example. Reinstating guaranteed home zone enrolment has not solved all the problems in school planning in areas of rapid growth, however. Overcrowded schools have difficulties determining how many students to accept, as they are unable to predict how many students will apply for enrolment during the academic year (Evans, 2002; Fiske \& Ladd, 2000). This is especially difficult for popular schools in areas of rapid growth, where student numbers can increase unpredictably from year to year. This suggests that enrolment policies that allow choice are not without practical difficulties.

It could be argued that the numerous alterations to the intended policy of Tomorrow's Schools have moved the provision too far from central control (Breakwell, 1999, p. 13). The 2000 Education Amendment Act reverted to the ballot box of the 1989 legislation (with added safeguards to ensure fairness) as a means to select out-of-zone enrolments (Rae, 2000). But clearly the ability of the 2000 amendments to fine-tune school enrolment policy is an area requiring further study.

\section{What the data mean}

It is important to note that the studies that discuss socio-economic indicators were unable to compare the ranking of schools prior to the reforms with their decile ratings in the 1990s. This is because the school decile ratings were developed in 1994, using the ethnic breakdown of students in conjunction with Census 1991 meshblock data, updated in 1997 by using Census 1996 data (Fiske \& Ladd, 2000, p. 184). It is also questionable whether including ethnicity in this measure is a valid means of determining SES, when set alongside other criteria that are clearly linked toSES, for example gross annual income, occupation, and educational qualifications (Elley \& Irving, 1985). For this reason, decile rankings do not give a "pure" measure of SES. However, the decile system gives a possible indication of the general background of the school community, and it is a measure that can feed into perceptions parents have of schools, without their knowing exactly how the rating is calculated.

Chubb and Moe (1990) discuss how state intervention in the United States provides mechanisms to ensure that no schools are underenrolled. This is designed to ensure that schools do not enter into a spiral of decline, through large and uncontrollable reductions in enrolments. It contrasts sharply with the New Zealand experience, where policies of devolution mandated a lack of government intervention at the local level.

The United States data illustrate that there are a number of different choice options available. For example, some policies offer home zone guaranteed enrolment, whereas others require all students to exercise free choice (Henig, 1994). Also, in the context of international discussion of school choice policies, it is noteworthy that New Zealand's policy prior to the 2000 legislation could be interpreted as promoting exit as a means to improve schools that are under-performing. This represents an extreme view of choice, and was probably not envisaged by members of the original Picot committee, who may have seen the policy they advocated simply as a means of adjustment of school rolls at the margins. Other countries, whilst offering exit, if that is the preference of parents, promote the use of parents and the community in using their voice as a means of improving their schools (Butterworth \& Butterworth, 1998).

New Zealand data suggest that removing zoning led to increasing polarisation of student enrolment (Fiske \& Ladd, 2000, p. 308). Conversely, many choice advocates in the United States highlight data that show no such trend (Schneider et al., 2000). However, the success of policies to reduce ethnic or economic polarisation is likely to be dependent on the demographic makeup of the school district itself. In the United States many inner city districts have a high proportion of ethnic minorities, whereas suburban areas are generally predominantly white (Kemerer, 1999).

When considering ethnic segregation in the United States, some states use magnet schools as a means for balancing racial attendance in many school districts (Goldring, 1997, p. 92). Their enrolments are regulated to ensure they achieve de-segregation. However, Goldring critiques both the United States and Israeli systems where, even with regulation, there is evidence of increased selection of students with higher SES backgrounds (p. 96). As in New Zealand, these findings occur across all ethnic groups, suggesting that SES is a strong 
determining factor in the selection of students, either by schools or parents. However, it is important to acknowledge that regulations imposed in the United States differ considerably from the those in the deregulated New Zealand school system, and definitions and criteria of choice may also vary. Due caution should be exercised in drawing comparisons.

\section{Conclusion}

This review shows a clear trend for increased socio-economic and ethnic segregation after the publication of the Picot Report and the Tomorrow's Schools documents (Department of Education, 1998a, 1988b). These trends were exacerbated by amendments in 1991, allowing open enrolment and increased devolution to schools. The data suggest that greater parental choice was not achieved after the removal of zoning. Furthermore, due to the changes in enrolment scheme policy, enrolment schemes allowed increased choice for some parents, but produced restricted choice, or no choice, for others. There is evidence that the compulsory ballot of out-of-zone places allowed for parental choice in the initial stages of these policies. Nevertheless, when the ballot was removed, schools that chose to select students by other means did so, to the detriment of some groups. It may not be the initial policy that warrants criticism, but the extent to which it was amended, which creates difficulty when the "fallout" from removing zoning is being considered.

Perhaps the resulting argument should rather be about who maintains control over student enrolment, as the provisions in the Picot Report and Tomorrow's Schools document suggest a level of government involvement, through use of a home zone and ballot. The aim of these policies was to increase parental and student choice. However, as the policy was amended, there was a shift toward less state intervention, and greater school control, at the expense of some students' choice options. Further legislative amendments in 1999 and 2000 attempted to reverse the 1991 policy changes. But the unfolding New Zealand experience suggests that it is schools that have increased choice rather than students or their parents.

Choice policies need to take into account the balance between the interests of parents and requirements of the system as a whole. Choice policy is not just a government issue, but an important social issue, and not easy to resolve. Allowing parents the option to choose, but applying state intervention to ensure balanced intakes, may reduce the perceptions of advantage or disadvantage linked to some schools and students. Although enrolment schemes cannot allow all students their first choice of school, discussion of possible alternatives has not brought to light a clearly better option. The Education Amendment Act 2000 addressed the need for transparency for parents and students by ensuring that all schools operating an enrolment scheme specify their home zone, and reinstated the compulsory ballot of out-of-zone places. This legislation has considerable merit, as it guarantees enrolment and enforces a process of selection that is transparent and equitable, as all students applying for remaining places have equal chance of selection.

\section{Note}

1. An interesting topic for further research would be an analysis of the relative numbers of students gaining acceptance into their secondary school of choice, and who are also receiving High Needs funding from the Ongoing and Reviewable Resourcing Schemes (ORRS), as part of SE2000 Special Education policy.

\section{References}

Ainsworth, V., Anderson, T., Clements, C., Heggies, S., Rogers, R., \& Martin, D. (1993). Tomorrow's schools and freedom of choice - a recipe for disaster: A study of the effects of roll changes on Christchurch state schools. Christchurch: University of Canterbury.

Breakwell, J. (1999). "The Pendulum Swings" - back to reasonably convenient schools. Australia and New Zealand Journal of Law and Education, 4(2), 3-17.

Butterworth, G., \& Butterworth, S. (1998). Reforming education: The New Zealand experience 1984-1996. Palmerston North: Dunmore Press.

Chubb, J. E., \& Moe, T. M. (1990). Politics, markets and America's schools. Washington, DC: Brookings Institution.

Collins. (1993). Collins English Dictionary and Thesaurus. Glasgow: Harper Collins Publishers.

Department of Education. (1988a). Administering for excellence: Effective administration in education (Picot Report). Wellington: Government Printer.

Department of Education. (1988b). Tomorrow's Schools: The reform of education administration in New Zealand. Wellington: Government Printer.

Elley, W. B., \& Irving, J. C. (1985). The Elley-Irving socio-economic index: 1981 Census revision. New Zealand Journal of Educational Studies, 20, 115-128. 
Evans, S. (2002). Large schools seek law changes to deal with increased enrolment. New Zealand Education Review, 7(2), 4.

Fiske, E. B., \& Ladd, H. F. (2000). When schools compete: A cautionary tale. Washington, DC: Brookings Institution.

Goldring, E. B. (1997). Parental involvement and school choice: Israel and the US. In R. Glatter, P. A. Woods, \& C. Bagley (Eds.), Choice and diversity in schooling: Perspectives and prospects (pp. 86-101). London: Routledge.

Gordon, L. (1997). Tomorrow's schools today: School choice and the education quasi-market. In M. Olssen \& K. Morris-Matthews (Eds.), Education policy in New Zealand: The 1990s and beyond (pp. 65-82). Palmerston North: Dunmore Press.

Harker, R. (2000). Roll change and the removal of zoning, 1991-1998, set: Research Information for Teachers, No. 2, 4-6.

Henig, J. R. (1994). Rethinking school choice: Limits of the market metaphor. Princeton: Princeton University Press.

Henig, J. R. (1999). School choice outcomes. In S. D. Sugarman \& F. R. Kemerer, (Eds.), School choice and social controversy: Politics, policy and law (pp. 68-107). Washington, DC: Brookings Institution.

Hughes, D., Lauder, H., Watson, S., Hamlin, J., \& Simiyu, I. (1996). Markets in education: Testing the polarisation thesis. The Smithfield Project Phase Two. Wellington: Ministry of Education.

Kemerer, F. R. (1999). School choice accountability. In S. D. Sugarman \& F. R. Kemerer, (Eds.) School choice and social controversy: Politics, policy and law (pp. 174-211). Washington, DC: Brookings Institution.

Lauder, H., Hughes, D., Waslander, S., Thrupp, M., McGlinn, J., Newton, S., \& Dupuis, A. (1994). The creation of market competition for education in New Zealand: An empirical analysis of a New Zealand secondary school market, 1990-1993. Wellington: Ministry of Education.

Lauder, H., Hughes, D., Watson, S., Simiyu, I., Strathdee, R., \& Waslander, S. (1995). Trading in futures: The nature of choice in educational markets in New Zealand. The Smithfield Project Phase 1, Report 3. Wellington: Ministry of Education.

Martin, S. (1998). Choosing a secondary school: Is it the same as buying a new washing machine? Paper presented at the Biennial Conference, New Zealand Educational Administration Society, January 11-14, Wellington.
Ministry of Education. (1998). New Zealand schools 1997. Wellington: Learning Media.

Peterson, P. E. (1998). School choice: A report card. In P. E. Peterson \& B. C. Hassel (Eds.), Learning from school choice (pp. 3-32). Washington, DC: Brookings Institution.

Prebble, T. K., \& Halford, W. D. (1986, November). The effects of falling rolls on secondary school enrolment policies. Delta, 38, 13-21.

Rae, K. (2000, December). Ki te ara tuatoru: School enrolment schemes and a possible third way in the administration of the school sector in Aotearoa New Zealand. New Zealand Journal of Educational Administration, 15, 49-60.

Real Estate Institute of New Zealand. (2001, September). Suspension for assisting to circumvent school zoning eligibility by confirming fake tenancy. New Zealand Real Estate, pp. 7-10.

Schneider, M., Teske, P., \& Marschall, M. (2000). Choosing schools: Consumer choice and the quality of American schools. Princeton: Princeton University Press.

Statistics New Zealand. (2001). 2001 Census of population and dwellings. Wellington: Statistics New Zealand.

Thrupp, M. (1999). Schools making a difference: Let's be realistic! Buckingham: Open University Press.

Waslander, S., \& Thrupp, M. (1995). Choice, competition and segregation: An empirical analysis of a New Zealand secondary school market, 1990-93. Journal of Education Policy, 10(1), 1-26.

Wylie, C. (1994). Self managing schools in New Zealand: The fifth year. Wellington: New Zealand Council for Educational Research.

Wylie, C. (1998). Can vouchers deliver better education? A review of the literature, with special reference to New Zealand. Wellington: New Zealand Council for Educational Research.

\section{The author}

Carrie Beaven is currently employed in the education sector in New Zealand, and has had previous experience as a primary school teacher. She has a keen interest in education from both a practical and academic perspective, and wrote this paper as a contribution towards her MEd study at Victoria University of Wellington, where she aims to continue her research in matters of educational policy, special education and "at risk" students. 